\title{
Seasonal Energy Experimental Evaluation of a SBFBR for Treatment of the Azo Dye Direct Red 23
}

\author{
Morales-Guzmán F. ${ }^{1}$, Romero R. J. ${ }^{2}$, Domínguez-Patiño M. L. ${ }^{2}$, Rodríguez-Martínez A. ${ }^{2}$ \& Melgoza-Alemán \\ Rosa María ${ }^{1}$ \\ ${ }^{1}$ Facultad de Ciencias Químicas e Ingeniería, Universidad Autónoma del Estado de Morelos, Av. Universidad \\ 1001. Col. Chamilpa C.P. 62209, Cuernavaca, Morelos, México \\ ${ }^{2}$ Centro de Investigaciones en Ingeniería y Ciencias Aplicadas, Universidad Autónoma del Estado de Morelos, \\ Av. Universidad 1001. Col. Chamilpa C.P. 62209, Cuernavaca, Morelos, México \\ Correspondence: Melgoza-Alemán Rosa María, Facultad de Ciencias Químicas e Ingeniería, Universidad \\ Autónoma del Estado de Morelos, Av. Universidad 1001. Col. Chamilpa C.P. 62209, Cuernavaca, Morelos, \\ México.E-mail: rmelgoza@uaem.mx \& rosenberg@uaem.mx
}

Received: October 1, 2012 Accepted: October 22, 2012 Online Published: December 6, 2012

doi:10.5539/eer.v3n1p1 URL: http://dx.doi.org/10.5539/eer.v3n1p1

\begin{abstract}
This paper shows the experimental energy evaluation for a Sequencing Batch Fluidized Bed Reactor (SBFBR) anaerobic/aerobic. The SBFBR was installed for the treatment of the Direct Red 23 azo dye (DR23 C. I. 29160). The evaluation of energy was made for summer and winter seasons. DR23 was selected for study because is not quickly biodegraded. DR23 is one of the most used dyes in the textile industry and it is used to dye cotton, linen and rayon fibers. DR23 is stable to light, easily absorbed in the water and its degree of fixation in the fiber goes from 70 to $95 \%$. The SBFBR was packed with granular activated carbon (CAG) as support of the biomass and as redox mediator for acceleration reaction rate by the transport of equivalent reducers between the electrodonor and electroacceptor compounds. A mixture 50/50 of activated sludge from two treatment plants was used as inoculums. Synthetic wastewater was composed with DR23 as substrate, $25 \mathrm{mgL}^{-1}$; acetic acid as co-substrate15 $\mathrm{mgL}^{-1}$ and basal medium. The strategy of fixed efficiencies was used for the acclimatization of the biomass to the DR23 and to the changes of environmental anaerobic/aerobic. The reactor was operated by 160 days ( 253 cycles) The acclimatization was reached in 43 days in the cycle 27 . The reaction time was reduced from $72 \mathrm{~h}$ to $24 \mathrm{~h}$. The concentrations of azo DR23 were increasing of 25 to $200 \mathrm{mgL}^{-1}$ with global removal efficiency of $95 \%$ of DR23. The reactor SBFBR anaerobic/aerobic was evaluated for the treatment of the DR23 azo dye and their metabolites secondary's that are aromatics amines. The thermodynamic evaluation was made for 27 cycles of operation of SBFBR in each operation temporary. Finally the total energy balance of process during summer and winter was evaluated and shows a energy consumption of 20 and $26 \mathrm{MJ}$ respectly added to the SBFBR.
\end{abstract}

Keywords: energy evaluation, fluidized bed reactor, sequencing batch reactor, DR23 azo dye, anaerobic/aerobic process, textile effluent

\section{Introduction}

Elimination of colour from textile wastewater is necessary for industrial reuse purposes. The textile industry consumes approximately $60 \%$ of the total production of dyes. For textile processing, inefficiencies in dyeing leads to wastewater, which go to the environment. The amount of dye lost is function of the class of dye application, from $2 \%$ to $50 \%$ loss when reactive azo dyes are used (McMullan et al., 2001). Residual of dyes are delivered in residual waters for treatment systems before it goes to the environment, and that causes contamination of rivers and underground water in the areas with high concentration of textile industries (Chudgar, 1985; Stolz, 2001).

Azo dyes are xenobiotics compounds characterized by the presence of one or more azo groups $(-\mathrm{N}=\mathrm{N}-)$. More than $50 \%$ are azo dyes from production of dyes, and around 2000 of them are used in the textile, leather, plastics, paper, cosmetics and foods industries (Stolz, 2001). The azo dyes into textile effluents are not toxic, but the formed products of their anaerobic biotransformation are amines aromatic, these products are toxics and are identified as carcinogenic and mutagenic compound (Cheng et al., 1997; Pinheiro et al., 2004). 
DR23 is used in the dyed of cotton fibbers, linen and rayon; it is stable to the light and it is absorbed easily in the water, its fixation grade in the fibber is from 70 to $95 \%$ (O’Neill et al., 1999). In the Figure 1 the chemical structure of the DR23 is shown.<smiles>CC(=O)Nc1ccc(N=Nc2cc3c(O)cc(NC(=O)Nc4ccc5c(O)c(N=Nc6ccccc6)c(S(C)(=O)=O)cc5c4)cc3cc2S(C)(=O)=O)cc1</smiles>

Figure 1. Chemical structure of direct red azo dye 23 (RD23 CI 29160)

An alternative treatment of RD23's effluents is the application of biological processes conventionally combining ambient anaerobic and aerobic integrated in a reactor. In these systems, reductive phase generates aromatic amines are secondary byproducts of the anaerobic reduction of the azo dye due to biotransformation. These byproducts are not generally biodegraded in this stage but in an oxidative phase during aerobic conditions they are mineralized to $\mathrm{NO}_{3}, \mathrm{~N}_{2}, \mathrm{CO}_{2} \mathrm{yH}_{2} \mathrm{O}$ and in this way their carcinogenic and mutagenic character is eliminated (Tan et al., 1999; O'Neill et al., 1999; Melgoza et al., 2004). This can be a method for the complete removal of azo dyes of the wastewaters. However, they present two limitations: the long retention time that frequently is applied in the anaerobic phase and the lack of knowledge on the fate of the aromatic amines in the aerobic phase for the biological and chemical transformations that will continue having the remainders of toxic aromatic amines in final effluents. Therefore it is important to assure a grade of mineralization of the aromatic amines (Van der Zee et al., 2005).

\section{Methodology}

\subsection{Experimental System}

It was installed a discontinuous sequencing batch fluidized bed reactor (SBFBR) with expanded bed at pilot level. The size of the SBFBR are shown in the Table 1. Three pumps and an aeration pump were connected to a programmable clock, with the purpose of controlling the load, recirculation, aeration and the discharges, all detailed in Table 2 .

For the duration of the aerobic phase the air was diffused from the bottom of the reactor through a porous diffuser. The temperature was controlled to $30 \pm 1{ }^{\circ} \mathrm{C}$, by means of a recirculation and heating of the water system (Poly Science Model 210). Electrodes of $\mathrm{pH}$, potential redox (ORP), nitrates, nitrogen amoniacal and dissolved oxygen were installed to the reactor.

Table 1. SBFBR Dimension

\begin{tabular}{lll}
\hline Wall & Acrilic & double \\
\hline height & 58 & $\mathrm{~cm}$ \\
Internal diameter & 14 & $\mathrm{Cm}$ \\
Total volume & 9 & $\mathrm{~L}$ \\
Packed & 2.0 & $\mathrm{Kg}$ of actived carbon \\
\hline
\end{tabular}


Table 2. Instrumentation

\begin{tabular}{lll}
\hline Liquid Pump & peristaltic of variable speed & Master Flex Cole Parmer Model 72200-62, 77601-10 \\
\hline Aeration pump & Immersion & Elite 802 \\
Control & Timer & Cole Parmer Programable timer \\
Temperature control & Recirculation & Poly Science Model 210 \\
pH, ORP, $\mathrm{O}_{2}$ & Electrodes & Cole Parmer \\
\hline
\end{tabular}

\subsection{Substrate Characteristics, Biomass and Operating Conditions}

The reactor was inoculated with a mixture of aerobic activated sludge from two wastewater treatment plants, a municipal wastewater and other industrial waste water in 50:50 ratios. The reactor was packed with $2 \mathrm{Kg}$ of granular activated carbon. The biomass concentration was $4.200 \mathrm{mg} \mathrm{L}^{-1}$. Synthetic wastewater was prepared with $25 \mathrm{mgL}^{-1} \mathrm{DR} 23,15 \mathrm{mgL}^{-1} \mathrm{CH}_{3} \mathrm{COOH}$ as co-substrate (used as source of carbon and electrons for complete the reduction reactions) in 1:8 molar ratio (DR23: $\left.\mathrm{CH}_{3} \mathrm{COOH}\right)$ and basal medium with the following composition $\left(\mathrm{mg} \mathrm{L}{ }^{-1}\right): \mathrm{K}_{2} \mathrm{HPO}_{4}(65.25), \mathrm{Na}_{2} \mathrm{HPO}_{4} \cdot 2 \mathrm{H}_{2} \mathrm{O}$ (100.2), $\mathrm{KH}_{2} \mathrm{PO}_{4}$ (25.5), $\mathrm{NH}_{4} \mathrm{Cl}$ (7.5), $\mathrm{MgSO}_{4} \cdot 7 \mathrm{H}_{2} \mathrm{O}$ (22.5), $\mathrm{CaCl}_{2} \cdot 2 \mathrm{H}_{2} \mathrm{O}(27.5), \mathrm{FeCl}_{3} \cdot 6 \mathrm{H}_{2} \mathrm{O}(0.25), \mathrm{H}_{3} \mathrm{BO}_{3}(0.06), \mathrm{MnSO}_{4} \cdot \mathrm{H}_{2} \mathrm{O}(0.04), \mathrm{ZnSO}_{4} \cdot 7 \mathrm{H}_{2} \mathrm{O}(0.04),\left(\mathrm{NH}_{4}\right) 6 \mathrm{Mo}^{2} \mathrm{O}_{24}$ (0.03) and EDTA (0.1). For the acclimatization of biomass to DR23 and varying environments anaerobic and aerobic, we used the fixed efficiency strategy, which consisted in allow to acclimate the biomass the time required for reduction DR23 80\% during the anaerobic phase and in the aerobic phase to eliminate $80 \%$ of the biotransformation of AAT (Melgoza et al., 2000)

\subsection{Analytic Methods}

The analyzed parameters were $\mathrm{pH}$, ORP (oxide-redox potential), temperature, total alkalinity as $\mathrm{CaCO}_{3}, \mathrm{CO}_{2}$, dissolved oxygen, SST (total suspended solids), SSV (volatile suspended solids), SS (solid sedimentables), sulfurs, sulfates and nitrogen as $\mathrm{N}-\mathrm{NH}_{4}$ and $\mathrm{N}-\mathrm{NO}_{3}$, they were carried out for standardized methods (APHA, 2005).

The determination of the DR23 was carried out in HPLC Agilent 1100 Series to $\lambda=501 \mathrm{~nm}$. The total aromatic amines were determined by the method of the p-dimethyl aminebenzaldehyde (Oren et al., 1991) spectrophotometer UV-VIS Agilent 8453E Spectroscopy System, measures to a wavelength of $440 \mathrm{~nm}$.

\subsection{Energy Analysis}

In order to evaluate the energy consumption for the SBFBR operation, 20 sensors in the experimental system were installed, as shown in the Figure 2. The sensors were connected to a data logger Agilent HP34970 with a personal computer. Measures of temperature were taken with the software HP-VEE Pro with programming directed to objects (Object Oriented Design OOD) focus in energy evaluation systems (Romero et al., 2007; Silva-Sotelo et al., 2010, Romero et al., 2013). Each one of the sensors was associated to the thermal balances to determine the thermodynamic behavior of the SBFBR in the cycle's operation.

$$
Q=C_{P} \frac{\partial(m T)}{\partial t}
$$

The used energy balance consider a constant of heat capacity $(\mathrm{Cp})$ with the value of $4.18 \mathrm{~kJ} \mathrm{~s}^{-1}{ }^{\circ} \mathrm{C}^{-1}$ and the characteristic flow of each pump, multiplied by the difference of temperatures in each reading.

$$
\frac{\partial(m T)}{\partial t}=m \frac{\partial T}{\partial t}
$$

Finally, it was evaluated the time that operated each pump to obtain the quantity of energy consumed in each cycle. The determination of time that heater maintains the controlled temperature of the SBFBR, the time of elevation of the registered temperatures was evaluated, obtaining as a result statistical the percentage of time in that it was turned on the heater.

$$
\frac{d T}{d t} \leq 0
$$

for a cooling time for both seasons. 


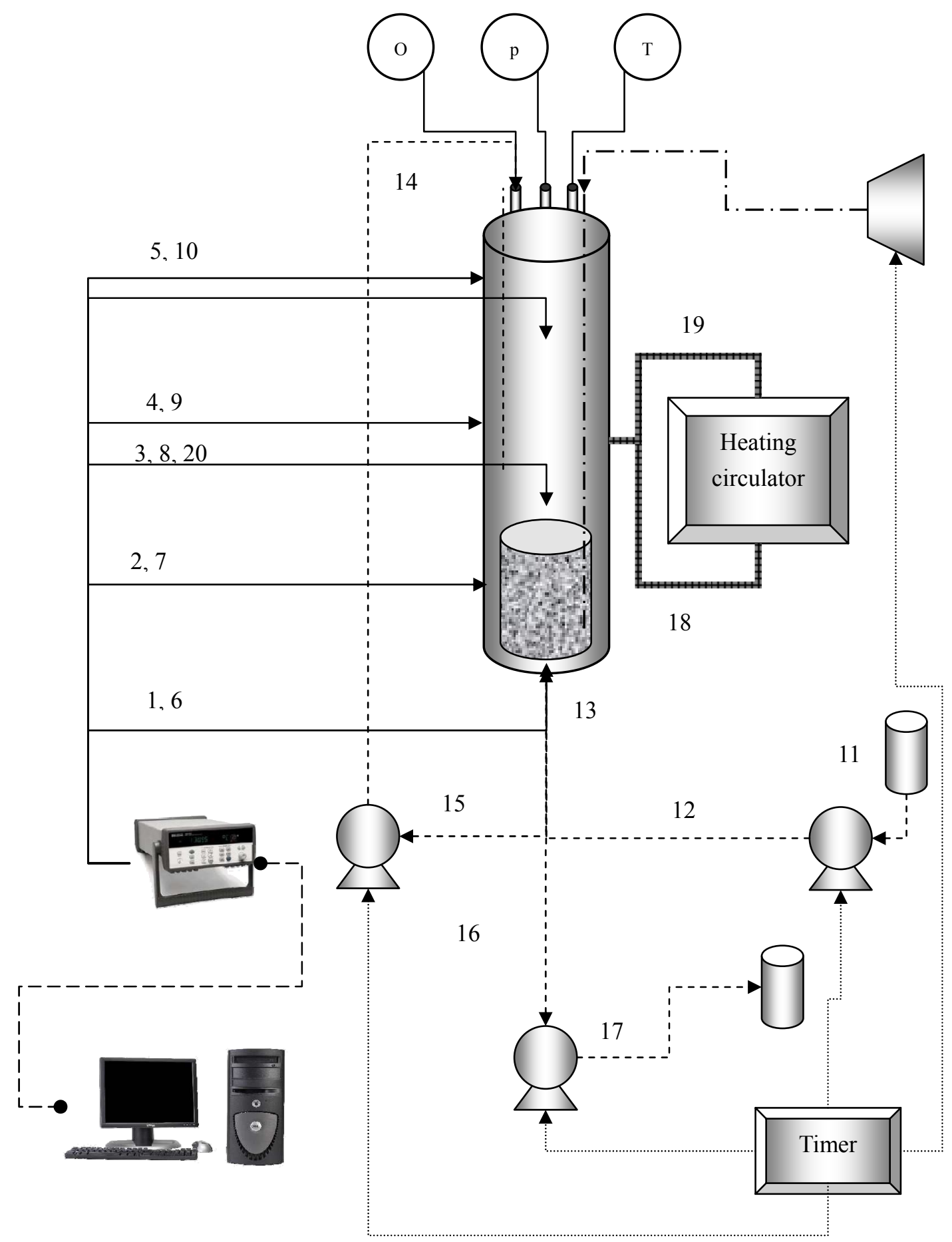

Figure 2. Diagram of the SBFBR anaerobic/aerobic for the treatment of the DR23

1,6 Bottom reactor (inside and outside)

$3,8,20$ To $20 \mathrm{~cm}$ bottom reactor (inside and outside)

5,10 To $50 \mathrm{~cm}$ bottom reactor (inside and outside)

2, 7 To $10 \mathrm{~cm}$ bottom reactor (inside and outside)

4, 9 To $30 \mathrm{~cm}$ bottom reactor (inside and outside)

11 Feed tank

$12 \quad$ Feed tank outlet
13 Reactor inlet

14 Water of recirculation outlet

15 Recirculator water inlet

16 Water unloading

17 Unloading point

18 Water to jacket inlet

19 Water of the jacket outlet 


$$
\frac{d T}{d t}>0
$$

for a heating time for both seasons.

Thermal analysis was conducted in the summer and winter seasons. In summer season for acclimatization of biomass and in the winter when the reactor was stabilized RD23 degradation. In both periods the operating conditions in concentration of DR23 and hydraulic retention times were similar.

Energy calculation was based on the determination of the energy that entered to the system so that they could be carried out the anaerobic and aerobic phases in each cycle, it was not considered useful the energy that left the system since didn't contribute energy to the pumps and the heater-recirculator of water.

\section{Results and Discussion}

\subsection{Performance of the SBFBR Anaerobic/Aerobic}

In the integrated biological processes for the treatment of azo dyes the operation strategy is a very important factor because the acclimatization of the bacterial population to the dye and anaerobic/aerobic environmental induces the microorganisms to develop its metabolic activities in presence or oxygen absence. The reactor operated during 253 cycles. The concentration of DR23 fed in the influent was increased as it was adapted to each operation condition. The acclimatization of SBFBR was achieved during the cycle 27 after 43 days. The thermal study was performed during cycles 19-25. Cycle 21 was a representative during acclimation of the reactor in the summer; subsequently thermal study was performed during the winter season in the same operating conditions that summer and the reactor power consumption was evaluated. The concentration initial was of 25 mg DR23 $\mathrm{L}^{-1}$, as it is observed in figure 3. The global removal of DR23 was stabilized to $85 \%$. After the acclimatization, the concentration of DR23 was increased of 25 to $200 \mathrm{mgL}^{-1}$. The global removal efficiency of DR23 was from 91 to $97 \%$, and the removal efficiency of color measured in units Pt-Co went from 92 to $98 \%$. In works carried out by (Tan et al., 1999, 2001), in a reactor of expanded bed for the treatment of the dye mordent yellow 10 (MY10/L), for a concentration from 59 to $65 \mathrm{mgL}^{-1}$ using ethanol as co-substrate, the removal efficiency of the MY10 was $100 \%$.

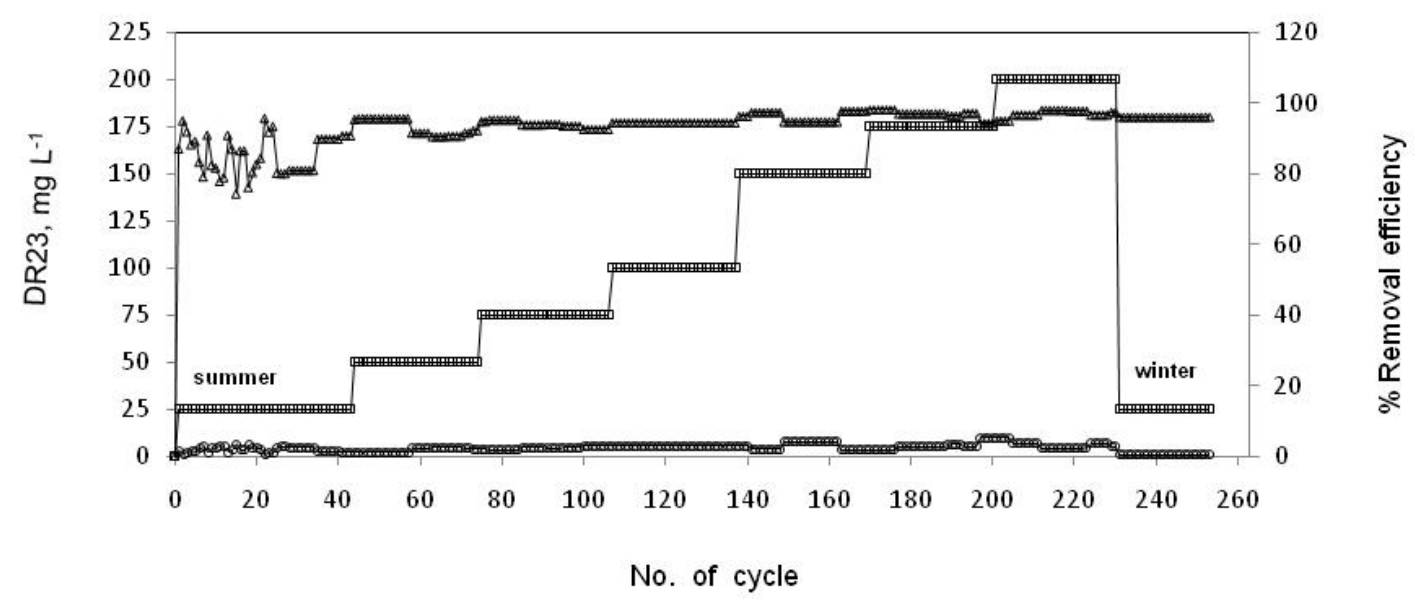

(-) Cycle start (०) Anaerobic phase end (-) Aerobic phase end ( $\Delta$ ) \% Removal efficiency

Figure 3. Performance of the SBFBR in the treatment of DR23

A summary of the operation of the SBFBR during the 253 cycles is shown in the Table 3 . The largest efficiency of removal of DR23 was reached during the anaerobic phase what suggests that acted as a rough treatment while the aerobic phase acted as a polishing treatment, suggesting that in the treatment of azo dyes in a process anaerobic/aerobic the aerobic phase serves as polish of the anaerobic effluent. In the most of the cases the anaerobic treatment doesn't eliminate the present compounds, but it transforms them in metabolites even more toxic that those of the influent. 
Table 3. Performance of the SBFBR in the treatment of the DR23

\begin{tabular}{|c|c|c|c|c|c|c|c|c|}
\hline $\begin{array}{l}\text { Operation } \\
\text { (days) }\end{array}$ & Cycles & $\begin{array}{l}\text { RHT anaerobic/ } \\
\text { aerobic }(\mathrm{h})\end{array}$ & $\begin{array}{c}\mathrm{S}_{\mathrm{i}} \\
\left(\mathrm{mg} \mathrm{L}^{-1}\right)\end{array}$ & $\begin{array}{c}\mathrm{S}_{\mathrm{ANA}} \\
\left(\mathrm{mg} \mathrm{L}^{-1}\right)\end{array}$ & $\begin{array}{c}\mathrm{S}_{\mathrm{AER}} \\
\left(\mathrm{mg} \mathrm{L}^{-1}\right)\end{array}$ & $\begin{array}{c}\text { Anaerobic removal } \\
\text { efficiency }(\%)\end{array}$ & $\begin{array}{l}\text { Aerobic removal } \\
\text { efficiency }(\%)\end{array}$ & $\begin{array}{l}\text { Global removal } \\
\text { efficiency (\%) }\end{array}$ \\
\hline 43 & $1-43$ & $18 / 6$ & 25 & 5 & 4 & 80 & 4 & 84 \\
\hline 59 & $44-74$ & $8 / 4$ & 50 & 9 & 3 & 82 & 12 & 94 \\
\hline 75 & $75-106$ & $8 / 4$ & 75 & 12 & 5 & 84 & 9 & 93 \\
\hline 90 & $107-137$ & $8 / 4$ & 100 & 21 & 6 & 79 & 15 & 94 \\
\hline 106 & $138-169$ & $8 / 4$ & 150 & 11 & 6 & 93 & 3 & 96 \\
\hline 122 & $170-200$ & $8 / 4$ & 175 & 7 & 6 & 96 & 1 & 97 \\
\hline 137 & $201-230$ & $8 / 4$ & 200 & 20 & 6 & 90 & 7 & 97 \\
\hline 160 & $231-253$ & $18 / 6$ & 25 & 5 & 4 & 80 & 4 & 84 \\
\hline
\end{tabular}

For the anaerobic phase the maximum biotransformation of the DR23 by reduction to amines was $3 \%$. After in the aerobic phase the mineralization of amines was $80 \%$. In works carried out by FitzGerald and Bishop (1995), in the treatment of the dye orange acid 10 (AO10) for a concentration of $10 \mathrm{mgL}^{-1}$ using an anaerobic reactor of fluidized bed, the recovery of the amines was $<1 \%$. Likewise, in carried out works by Sarsour et al. (2001), in an anaerobic-aerobic coupled system for a concentration of $5000 \mathrm{mgL}^{-1}$ of reactive red 198 (RR198), using starch as co-substrate, the amines recovery were from 2 to $3 \%$. In this work, the time of reaction was optimized of 72 to $12 \mathrm{~h}(8 \mathrm{~h}$ anaerobic phase, $4 \mathrm{~h}$ aerobic phase). In general terms the redox potential during the experimental cycles was $-299 \mathrm{mV}$ in anaerobic phase and $+105 \mathrm{mV}$ in the aerobic phase. The reactor operated under reduction conditions in the anaerobic phase and oxidation conditions in the aerobic phase. These conditions are indispensable in this type of reactors that integrate anaerobic and aerobic environments.

Through entire experiment was not detected production of biogas only presence of $\mathrm{CO}_{2}$. The average total alkalinity was from 350 to $450 \mathrm{mg} \mathrm{CaCO} \mathrm{L}^{-1}$ which was enough buffer capacity to neutralize the volatile fatty acids during the process to avoid the inhibition of the biomass for acidification. The average $\mathrm{pH}$ was 7.0 in the anaerobic phase and 8.0 in the aerobic phase

\subsection{Energy Consumption in the Operation of SBFBR}

A cycle of operation of the SBFBR begins with the activation of the feed pump (ALI) which stayed on during 7 min to temperature ambient. After of the load of the reactor the pump was switch off. The anaerobic phase and the recirculation of the residual water began by means of pump (REC) during $19.88 \mathrm{~h}$. In the anaerobic phase energy was required to maintain the system to $30{ }^{\circ} \mathrm{C}$ (heating recirculator). Once concluded the anaerobic phase the pump (REC) was switch off and the aeration pump was activated (AIR) for one period of $3.88 \mathrm{~h}(23.76 \mathrm{~h}$ of global operation). After the pump (AIR) was switch off and the pump discharge (DAR) was on during 7 minutes. The energy consumed was based on the calculation of the energy that entered for the phases anaerobic and aerobic in each cycle, did not consider the energy useful that loged-off since it did not contribute energy to the pumps and to the water heater-recirculador.

In anaerobic and aerobic processes the temperature of the SBFBR was controlled to $30.0{ }^{\circ} \mathrm{C}$ by a recirculator-heater of water with a nominal power of $750 \mathrm{~W}$. It is necessary to mention that the recirculator-heater of water was switch on and it switch off automatically by the controller of temperature shown periods of $14.37 \%$ (on the average) of the time switch on and the rest of the time stayed out, therefore the energy consumption for each cycle of $24 \mathrm{~h}$ was of $9.32 \mathrm{MJ}$ for $9 \mathrm{~L}$ of wastewater for summer season and $15.00 \mathrm{MJ}$ in the winter season. The results of are shown in the Table 4.

Table 4. Energy consumption in each pump during the reactor operation

\begin{tabular}{lcc}
\hline Energy Consumption (MJ) & Summer season & Winter season \\
\hline Feed pump & 0.02 & 0.02 \\
Recirculation system & 10.74 & 10.74 \\
Aeration system & 0.05 & 0.05 \\
Discharge system & 0.02 & 0.02 \\
Heating system & 9.32 & 15.00 \\
Total energy & 20.15 & 25.83 \\
\hline
\end{tabular}


The ambient temperature for summer season was $25^{\circ} \mathrm{C}$ and in winter was $18^{\circ} \mathrm{C}$. The difference of temperature derives that consumption of energy in the heater for remaining the reactor at $30{ }^{\circ} \mathrm{C}$. In winter was approximately double time heater required than summer, as can be seen in Figures 4 and 5 showing the temperature profiles for each season. The heating zone is larger in winter than in summer.

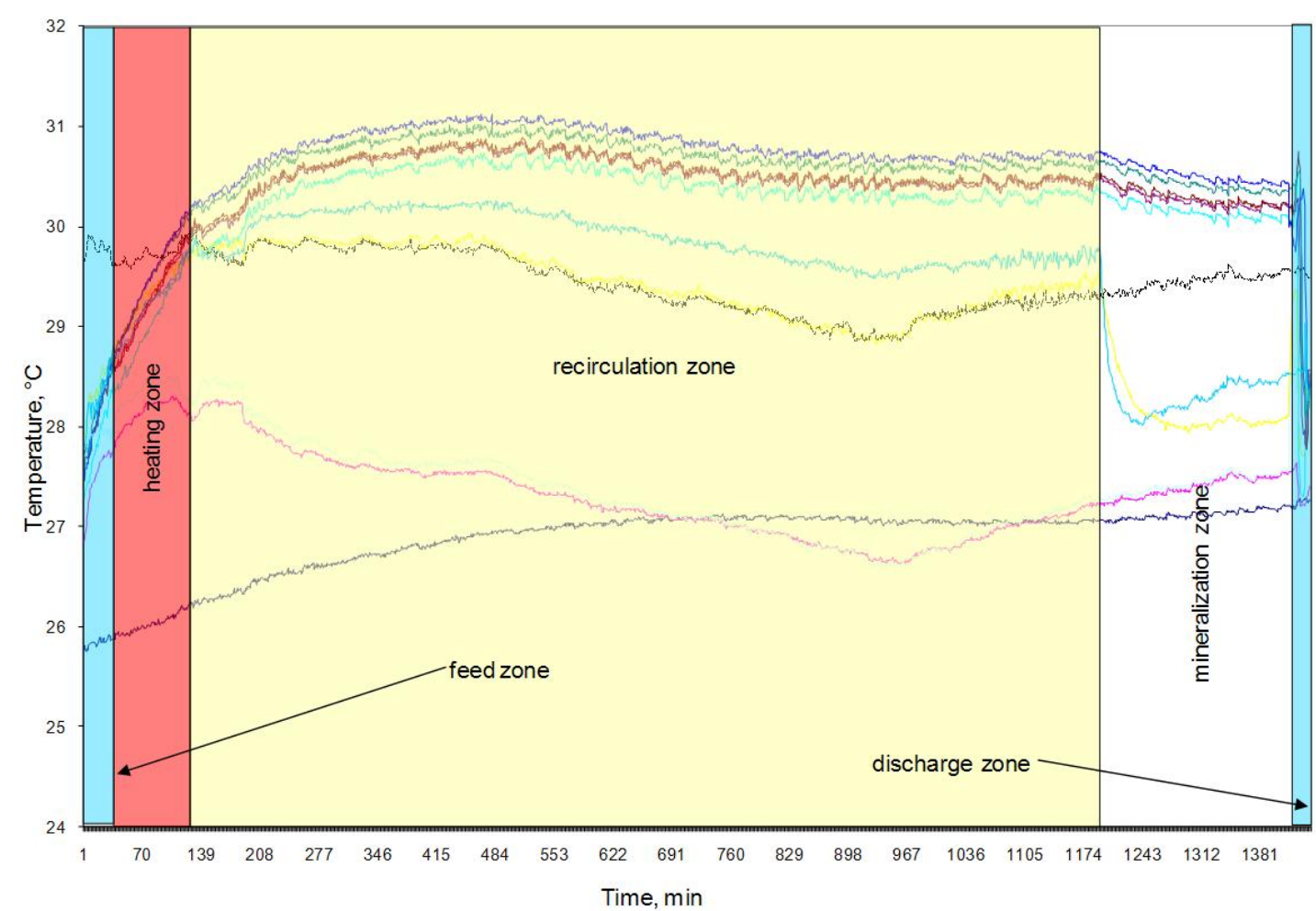

Figure 4. Temperature profile for summer season

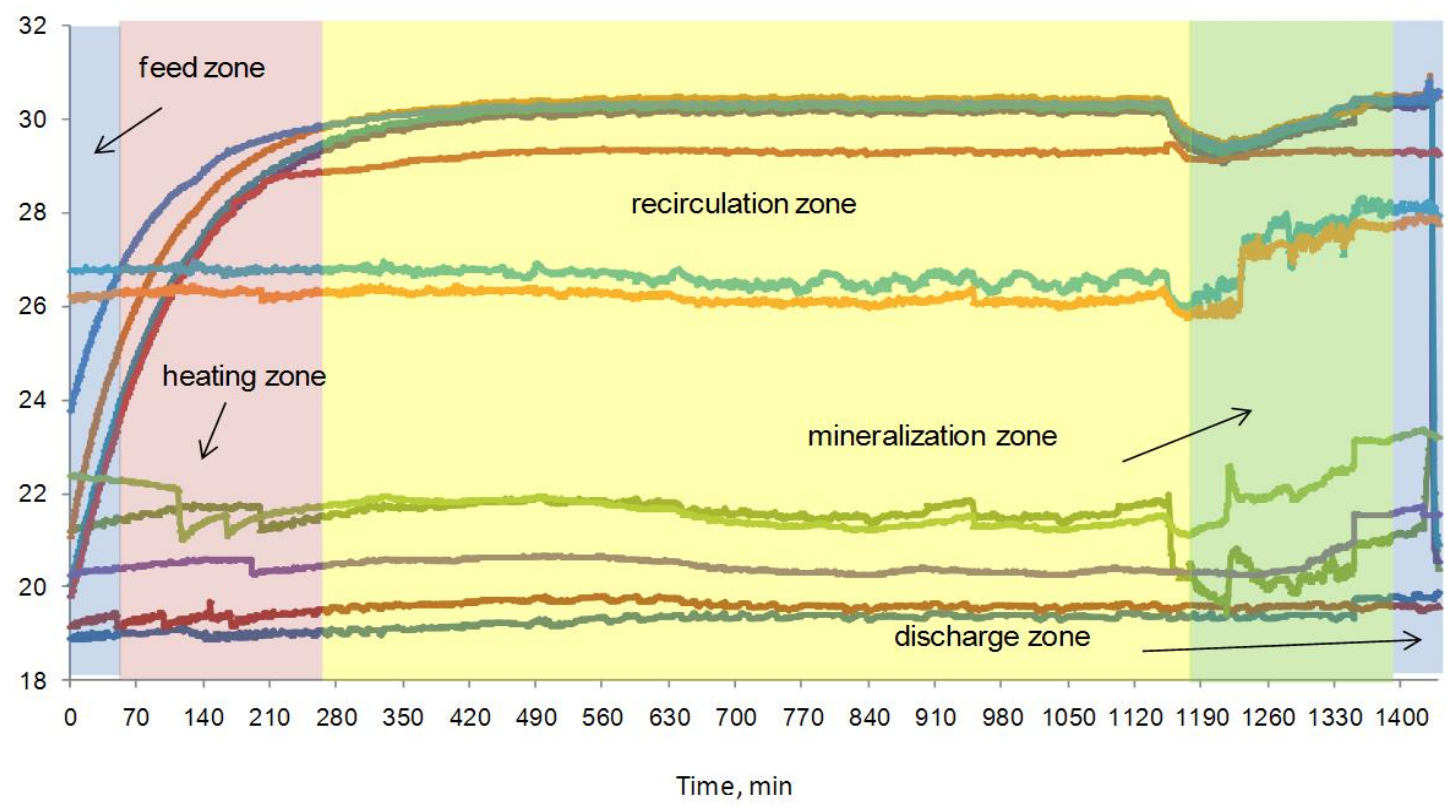

Figure 5. Temperature profile for winter season

The energy consumption at begin of the cycle was of $0.02 \mathrm{MJ}$ by load of the reactor, after were consumed 10.74 MJ by the anaerobic process. The aeration shown a relative low consumption of $0.05 \mathrm{MJ}$ and finally the energy consumption of unload was of $0.02 \mathrm{MJ}$. 
Figure 6 shows the analysis of temperature variation during SBFBR operation in the two seasons. The analysis indicated that in the summer at the entrance to the reactor had a total power consumption of $1.8 \mathrm{MJ}$ and the rest of the energy that entered the reactor is dissipated as heat (Q) to the environment. In winter analysis the temperature variation indicates that the system does not consume energy, it releases energy as heat in accordance with the negative values of $\mathrm{Q}=-7.51 \mathrm{MJ}$.

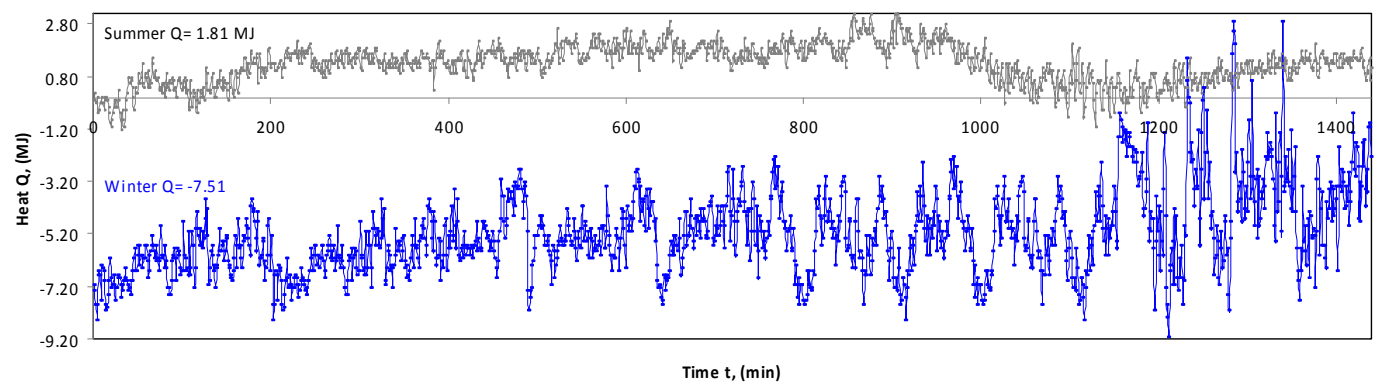

Figure 6. Analysis of variation of temperature during operation of the SBFBR, in the summer and winter seasons respectively

\section{Conclusions}

Energy consumption evaluation for the mineralization and the DR23 in a sequencing batch reactor of expanded bed was carried out in a pilot level; integrating anaerobic/aerobic environmental, alternating reductive and oxidative phases. In the reductive phase the biotransformation of the DR23 was reached and in the oxidative phases the mineralization of the amines to $\mathrm{CO}_{2}, \mathrm{H}_{2} \mathrm{O}$ and $\mathrm{NO}_{3}$ was also investigated.

The total of energy consumed in this process during one cycle of operation in the summer season was of 20.15 $\mathrm{MJ}$ and the winter season of $25.83 \mathrm{MJ}$.

The analysis of the variation of the temperature indicated that in summer season there is a total energy consumption of 1.8 MJ, while in winter season, the reactor did not consume energy provided the environment as the value obtained was negative which means that the energy leaving the system $(-7.51 \mathrm{MJ})$. In winter season was approximately double time that required in summer season so that the system reaches a temperature of 30 ${ }^{\circ} \mathrm{C}$.

The acclimatization period was 27 cycles for a concentration of $25 \mathrm{mg} / \mathrm{L}$ with a constant temperature of $30^{\circ} \mathrm{C}$ $\left(+/-1^{\circ} \mathrm{C}\right)$. The concentrations studied were from 25 to $200 \mathrm{mg} / \mathrm{L}$. The reaction times were diminished from 72 $\mathrm{h}$ (48 $\mathrm{h}$ phase anaerobia, $24 \mathrm{~h}$ aerobic phase) to $12 \mathrm{~h}$ ( $8 \mathrm{~h}$ anaerobic phase, $4 \mathrm{~h}$ aerobic phase). The global removal efficiencies of DR23 were from 84 to $97 \%$, the biotransformation of amines was of $3 \%$ and the mineralization of these was of $80 \%$.

\section{Acknowledgment}

Dr Romero wants to thank to 167434 CONACyT’ Basic Science Project for partial support.

\section{References}

APHA. (2005). Standard Methods for Examination of Water and Wastewater (21st ed.). Washington D. C. USA: American Public Health Association/American Water Works Association/ Water Environment Federation.

Cheng, J., Suidan, M. T., \& Venosa, A. D. (1997). Kinetic of anaerobic cometabolism of 2-4 dinitrotoluene with ethanol as the primary substrate. Water Science and Technology, 36(6-7), 271-278. http://dx.doi.org/10.1016/S0273-1223(97)00532-5

Chudgar, R. J. (1985). Azo dyes. In L. I. Kroschwitz (Ed.), Krk-Othmer Encyclopedia of Chemical Technology (4th ed., pp. 821-875). New York: Wiley.

Fitz Gerald, S. W., \& Bishop, O. L. (1995). Two stage anaerobic/aerobic treatment of sulfonated azo dyes. $J$. Environ. Sci. Health Part A-Toxic/Hazard. Subst. Environ. Eng., 30(6), 1251-1276.

McMullan, G., Meehan, C., Conneely, A., Kirby, N., Robinson, T., Nigam P., .., Smyth, W. F. (2001). Microbial decolourisation and degradation of textile dyes. Applied Microbiology and Biotechnology, 56, 81-87. http://dx.doi.org/10.1007/s002530000587

Melgoza, R. M., Chew, M., \& Buitrón, G. (2000). Start-up of a sequential anaerobic/aerobic batch reactor for the 
mineralization of p-nitrophenol. Water Science and Technology, 42(5-6), 289-292.

Melgoza, R. M., Cruz, A., \& Buitrón, G. (2004). Anaerobic/Aerobic Treatment of Colorants Present in Textile Effluents. Water Science and Technology, 50(2), 149-155.

O’Neill, C., Hawkes, F., Esteves, S., Hawkwa, D., \& Wilcox, S. (1999). Anaerobic and aerobic of simulated textile effluent. Journal Chemical Technology and Biotechnology, 74, 993-999.

Oren, A., Gurevich, P., \& Henis, Y. (1991). Reduction of nitrosubstituted aromatic compounds by the halophilic anaerobic eurobacteria Haloanarobium praevalens and Sporohalobacter marismortui. Applied and Environmental Microbiology, 57, 3367-3370.

Pinheiro, H., Touraud, E., \& Thomas, O. (2004). Aromatic amines from azo dye reduction: status review with emphasis on direct UV spectrophotometric detection in textile industry wastewaters. Dyes and Pigments., 61, 121-139. http://dx.doi.org/10.1016/j.dyepig.2003.10.009

Romero, R. J., Silva-Sotelo, S., Rodríguez, M., \& Cerezo, R. J. (2013). Energy Saving in Advanced Absorption Heat Pump with Object Oriented Programming. In Emerging Trends in Computing, Informatics, Systems Sciences, and Engineering, Lecture Notes in Electrical Engineering (Vol. 151, pp. 1101-1111). http://dx.doi.org/10.1007/978-1-4614-3558-7_94

Romero, R., Martínez, A., \& González, E. (2007). Laboratory instrumentation and object oriented design for working fluid control in an "absorption heat pump" using Water / Carrol. In Innovations and Advanced Techniques in Computer and Information Sciences and Engineering (pp. 429-432). http://dx.doi.org/10.1007/978-1-4020-6268-1_76

Russ, R., Rau, J., \& Stolz, A. (2000). The function of cytoplasmic flavin reductases in the reduction of azo dyes $\begin{array}{lllll}\text { by } \quad \text { bacteria. Appl. } & \text { Environ. }\end{array}$ http://dx.doi.org/10.1128/AEM.66.4.1429-1434.2000

Silva-Sotelo, S., Romero, R. J., \& Rodríguez-Martínez, A. (2010). Double Stage Heat Transformer Controlled by Flow Ratio. In Innovations in Computing Sciences and Software Engineering (pp. 577-581). http://dx.doi.org/10.1007/978-90-481-9112-3_100

Stolz, A. (2001). Basic and applied aspects in the microbial degradation of azo dyes. Applied Microbiology Biotechnology, 56, 69-80. http://dx.doi.org/10.1007/s002530100686

Tan, N. C. G., Prenafeta-Boldú, F. X., Opsteeg, J. L., Lettinga, G., \& Field, J. A. (1999). Biodegradation of azo dyes in cocultures of anaerobic granular sludge with aerobic aromatic amines degrading enrichment cultures. Applied Microbiology Biotechnology., 51, 865-871. http://dx.doi.org/10.1007/s002530051475

Tan, N. C. G. (2001). Integrated and sequential anaerobic/aerobic biodegradation of azo dyes. Ph D. thesis. Wageningen, The Netherlands: Wageningen University.

Van der Zee, F., \& Villaverde, S. (2005). Combined anaerobic-aerobic treatment of azo dyes - A short review of bioreactor studies. Water Research., 39, 1425-1440. http://dx.doi.org/10.1016/j.watres.2005.03.007 